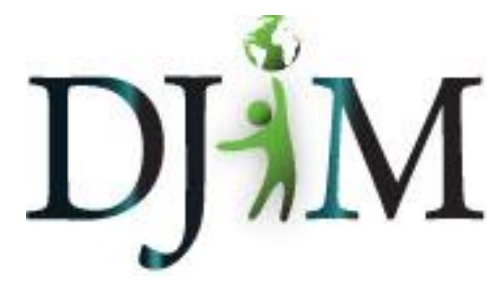

Volume 7 - Spring 2011 djim.management.dal.ca

\title{
The Reader's Devices: The Affordances of Ebook Readers
}

\section{Heather MacFadyen}

\begin{abstract}
Print books and ebook devices now co-exist in a reading ecosystem. The ways in which readers understand and describe their experience of reading on ebook devices is shaped by long-established cultural expectations about the abstract as well as the physical affordances of the print book. Ebook devices cannot help but challenge those expectations. A review of readers' reactions to the emergence of ebook devices offers a glimpse into the complex cultural position of both the idea and the experience of reading.
\end{abstract}

\footnotetext{
About the Author(s): Heather MacFadyen (MLIS Candidate, 2012) holds a Ph.D. in English Literature from the University of Ottawa. She has worked in a variety of corporate communication roles over the last decade and is very much looking forward to helping publish the work of Dalhousie graduate students in DJIM.
} 


\section{Introduction}

"I can't imagine a world when I don't smell a new book again" (Harland, et al., 2010): This is a typical reaction to the possibility that ebooks will replace print books. What makes this concern for the smell of a book remarkable is that it is almost entirely unrelated to the cognitive act of reading. Nevertheless, this sense of loss has captured the attention of readers. According to one survey, $43 \%$ of French students now consider the smell of a book to be a key aspect of their reading experience (Darnton, 2009, p. 54). Comments about the smell of books have become common enough to exasperate moderate ebook advocates: "I sometimes suspect that those who gush about book odor might not like to read" (Heffernan, 2010a). Most tellingly, the celebration of the scent of paper, ink, and glue has provoked parodic product development: Kindle owners are encouraged to improve their reading experience by purchasing aerosolized "Smell of Books" (DuroSport, 2010).

The positive association of smell and the reading experience is, however, a late 20th century phenomenon. The Reading Experience Database, which covers the years between 1450 and 1945 , records two references to the smell of a specific book. Only one of those references positively associates books and smell. While Gosse (1859) recalled the unpleasant mildewed smell of a Latin primer inherited from his grandfather as part and parcel of his reading experience, Burton (1900-1914) recalled the smell of a particular copy of a Jules Verne novel as part of contented familial reading experiences. Although an admittedly crude measure of cultural shifts, searches for the occurrences of the phrase "smell of books" in Google Books suggest that references to the smell of books are relatively scarce in books published before 1990 and proliferate over the next two decades. ${ }^{1}$ The increase of references to a book's smell is, in part, a consequence of a rise in the popularity of book collecting (Striphas, 2009), but more significantly, it coincides with the emergence of digital texts in general and digital reading devices in particular. The invocation of such an immaterial aspect of a print book is emblematic of the ways in which people try to fit the experience of digital reading into mental models derived from print culture; it also expresses uneasiness with impending changes in the cultural

\footnotetext{
${ }^{1}$ References to the smell of books are relatively scarce in books published before 1990, with 600 occurrences between 1900 and 1990. The following decade produces 763 occurrences and another 630 occurrences are recorded between 2000 and 2010. (Searches conducted in December 2010).
} 
landscape. ${ }^{2}$ The lament for the loss of scent is a nostalgic gesture that defends of the reading experience that ebook devices seem to threaten.

The ways users understand and describe their experiences of reading on digital devices are shaped by well-established cultural expectations about the abstract as well as the physical affordances of the print book. The concept of affordances was adapted from the realm of cognitive psychology by design and human-computer interaction fields as a way of teasing out the complex and often very subtle relationship between objects and their users. Affordances are those "fundamental properties" of an object that determine how the object can be used by a human being (Norman, 2002, p. 9). While the perceived affordances of a well-designed object provide clear and strong clues about its function to the user, the affordances of long familiar objects become invisible with use. These no-longer-seen affordances resurface in moments of cognitive failure or in moments of juxtaposition. A user who no longer perceives the relationship between the label "On/Off" and an adjacent rocker switch on a coffeemaker experiences a moment of cognitive failure that highlights an otherwise hidden affordance of an everyday object: depressing the left side of the rocker switch turns on the coffeemaker. The juxtaposition of an everyday object with a new object, which has similar but not entirely identical functions, can uncover everyday affordances. The presence of the ebook device in the reading ecosystem makes the affordances and cultural expectations of the print book visible through the force of juxtaposition. Once made visible, those affordances and the reading experiences they support are used to judge the viability and utility of ebook devices. The presence of ebook devices in the reading ecosystem provokes reactions that can be divided into two rough categories: those related to abstract affordances and those related to physical affordances. Responses that focus on the relationship of ebook devices to the smell of a book, for example, fall into the first category. Responses that focus on the ways pages are turned on an ebook device, in contrast, fall into the second category. A review of the reactions of people to the emergence of ebook devices offers a glimpse into the complex cultural position of both the idea and the experience of reading.

\section{Terminological Fluidity}

Although handheld devices used to read electronic texts have been part of the publishing, book selling, and book reading landscape for more than a decade, the terminology used to describe the elements that make up a digital reading ecology is still shifting and awkward (Armstrong, 2008). Depending on the context, an ebook might be a digitized facsimile of a paper book, an electronic text with only a passing resemblance to the paper book's form, an electronic text hyperlinked to many other texts, a type of software used to access digital texts, or a piece of hardware. An ebook reader can be both the mechanical device that displays a

\footnotetext{
${ }^{2}$ For articulation of the uneasiness caused by this transition, see Birkerts (1994), Levy (1997), and Carr (2010).
} 
sequence of letters and the person performing the cognitive act of recognizing and understanding that sequence of letters. ${ }^{3}$ The tendency for terms to encompass both content and enabling technology points to the unsettled status of digital reading practices. For the purposes of this paper, reader will be used to refer to the deciphering human being, ebook will be used to refer to the digital text, and ebook device will be used to refer to the handheld device that combines hardware and software and is used to display the ebook to the reader.

\section{A Brief History of Ebook Devices}

Ebook devices have passed through two waves of interest and adoption. The first wave occurred between 1998 and 2000 when multiple ebook devices entered the marketplace. Not surprisingly, these devices were received with a mix of skepticism and enthusiasm by an audience already accustomed to consuming digital text on personal computers. Tennant (2000), for example, thought it unlikely that ebook devices would replace paper books for pleasure reading but that they were "made-to-order for students" and an "excellent solution" for professionals needing to consult technical manuals (p. 38). Lynch $(1999 ; 2000)$ offered a thorough analysis of the challenges posed by ebook devices, many of which have remained largely unresolved. He pointed, for example, to the challenges that the proliferation of devices with incompatible software and text formatting requirements would pose to individuals and libraries. As well, Lynch highlighted the cultural, legal, and logistical complexities associated with digital rights management: Would ebooks be owned or leased? Would ebook owners be able to make copies for preservation purposes? Would libraries be able to lend ebooks through interlibrary loan programs? Would networked ebook devices erode readers' privacy? By 2001 there were 20 separate ebook devices being marketed in the United States (Herther, 2008). Few of these devices survived the collapse of the dot-com bubble in 2000-2001. By the time the high-tech sector recovered, interest in consumer devices shifted away from ebook devices and toward the increasingly multi-purpose mobile phone and the role it could play in a more interactive social web. ${ }^{4}$ Interest in ebook publishing and distribution remained strong within the domains of universities and scholarly publishing where digital infrastructures were widely implemented in an attempt to contain spiralling costs of serials. ${ }^{5}$

A second wave of interest in ebook devices occurred with the entrance of Amazon into the consumer device market in 2007. Amazon's commercial success is driven primarily by its

\footnotetext{
${ }^{3}$ For a detailed review of these terminological difficulties and their implications, see Armstrong (2008).

${ }^{4}$ For an early articulation of the nature of the social web, see O'Reilly (2005). For an exploration of the intersection of the social web and the business world, see Li and Bernoff (2008). For an exploration of the cultural and social implications of the social web, see Shirky (2008).

${ }^{5}$ For an exploration of the role of digital infrastructures in an academic context, see Borgman (2007).
} 
ability to contain costs and expedite shipping. Its expertise is largely logistical. While earlier ebook device manufacturers such as Sony focused on technology matters, Amazon's focus is primarily upon distribution and the Kindle expresses that focus. As a result, Amazon's entrance into the ebook device market signaled a shift in the terrain. The Kindle is as much a device used to buy books as it is a device used to read books. This shift in emphasis is echoed in the subsequent emergence of devices, such as the Nook or the Kobo, which are also coupled to specific book vendors. Early signs of a shift to a device-agnostic model can be seen in the ways in which Amazon has made it possible for customers to buy and read Kindle e-books on its competitors' devices. Ebook devices are likely to follow the trajectory of mobile telephones: the device itself will become a commodity and competitive advantage will be driven by goods and services offered through the device. Despite the changes in the technologies and services associated with ebook devices, there is considerable consistency in the ways in which the ebook reading experience is shaped by the observer's experience of the affordances of the printed book.

\section{Print Affordances and Ebook Devices}

Readers commonly bring to their digital reading a notion of private property that is based upon their experience of owning print books. Once purchased and placed on an individual's bookshelf, a print book has an unquestioned and invisible affordance of private ownership. Readers of print books expect to be able to lend their books to friends as well as to be able to exercise a right of first sale and to resell their books. ${ }^{6}$ The struggles over the use of digital rights management technologies to block the sharing or resale of ebooks are the most obvious, and most commented upon, property-related discontinuity between the print and electronic book environments (Armstrong, 2008; Bryant, 1995; Fowler \& Baca, 2010; Griffey, 2010; Herther, 2008; Levy, 2007). Despite sustained struggles over this gap between readers' expectations and publishers' strategies, the mismatch is unlikely to be resolved while the discourse about ebook devices conflates their book buying and book reading functions. Device users entranced with the speed with which books can be downloaded tend to overlook the economic transaction that precedes the download. When combined with digital rights management technologies, ebook devices challenge the concept of a fundamental right to sustained ownership of a purchased good by facilitating the ability of rights holders to control the circulation of goods past the point of purchase. Prescient concerns about threats to the property status of ebooks can be seen as early as 1998, when Machrone noted that the correspondents who responded negatively to his advocacy of ebooks and ebook devices were skeptical and suspected that vendors would neither protect the book buyers' property nor their privacy rights.

\footnotetext{
${ }^{6}$ Struggles over private book lending are not a new phenomenon; see, for example, Striphas (2009) on publishing industry campaigns against the "book sneak" in the 1930s.
} 
The fragile nature of ebook ownership was brought home to ebook enthusiasts and opponents alike in the summer of 2009. After discovering that it had sold an edition of George Orwell's 1984 for which it did not have electronic distribution rights, Amazon deleted the book from its customers' Kindles. Not surprisingly, reactions to Amazon's use of its ability to control the contents of its customers' ebook devices concentrated on questions of property rights and privacy (Findlay, 2010; Pogue, 2009; Raab, 2010; Striphas, 2010). The deletion of the ebook also removed the connection between the text and any notes added by readers as a way of recording their reading experience. Arguing that the deletion of 1984 had destroyed the value of their annotations, readers brought class action lawsuits against Amazon which were quickly settled out of court for $\$ 150,000$ (Striphas, 2010). This combination of the deletions and the lawsuits makes another key affordance of print books visible: the relative permanence and privacy of annotations made in print books. Readers of print books expect that evidence of their interactions with their books will remain part of their private realm as long as they own the book. The various marks-whether a pencilled line, a stripe of yellow highlighter, or an electronic annotation-record the passage of the reader through the text and are both visible signs of engagement and distinct pieces of intellectual property. ${ }^{7}$ The meaningfulness of any individual note is largely dependent on its remaining connected to or associated with the text upon which it comments. By deleting the ebook and breaking the association between the ebook and its reader's notes, Amazon called into question the print-based certainty that annotations are private and under the control of their creator.

Amazon's use of its cloud computing and data mining abilities to circulate once-private annotations to all Kindle owners has similarly unsettled users of ebook devices. ${ }^{8}$ The Kindle makes the least complex form of individuals' annotations-underlined or highlighted passages-public in an aggregate form. For some readers, this aggregation and circulation is disturbing: the abstract representation of other readers' marks in a newly-purchased book becomes "a violation of virgin text" and becomes particularly annoying by unhelpfully exaggerating the importance of the most clichéd passages. (Heffernan, 2010b). While the "chorus of readers" may sometimes point the solitary reader to "the good bits" (Johnson, 2010), the Kindle's sharing of the reading experience jolts that same solitary reader into an awareness that reading is "only superficially solitary" (Heffernan, 2010b). This jolt uncovers a critical affordance of the print book: it supports both the practice of solitary or private reading and is a foundational element in an "ideology of solitary reading" that privileges individual experiences while underestimating the role of more sociable reading (Griswold, McDonnell, \& Wright, 2005).

\footnotetext{
${ }^{7}$ For an account of the history and function of marginalia, see Jackson (2001).

${ }^{8}$ For an analysis of the implications of Amazon's data mining practices and liberal theories of free expression, privacy, and autonomy, see Striphas (2010).
} 
While privacy remains a valuable affordance of the print book and informs readers' reaction to ebook devices, those devices are simultaneously and paradoxically identified as a threat to the publicity functions of print books. Readers on public transit who use ebook devices are suddenly no longer subject to the scrutinizing gaze of strangers, making for "poorer peoplewatching" and fewer public displays of reading tastes (Oder, Albanese, \& Kuzyk, 2009). Not surprisingly, readers somewhat ashamed of their reading preferences relish the ways ebook devices protect them from prying gazes. The ebook device is the "digital equivalent of the brown-paper wrapper" (Bosman, 2010). In contrast, readers hoping to use a display of books to signify their social status are singularly thwarted by ebook devices: "How do I display or otherwise admire all these books I keep buying for the Kindle?" (Heffernan, 2010a). Any status that might once have been accrued by a physical collection of books tends, therefore, to be transferred to a specific material affordance of the ebook device itself: its near weightlessness.

One of the most praised affordances of the ebook device is its ability to hold entire libraries and thereby make the weight of reading material a trivial matter. Commentators focused on the academic potential of ebooks have consistently praised ebook devices for saving the backs of students overburdened with textbooks (Baumann, 2010; Foderaro, 2010; Gregory, 2008; Marshall \& Ruotol, 2002; Shelburne, 2009; Waycott, 2002). In the popular press, this praise tends to be coupled to the notion of air travel. In an extended bit of promotion of the Kindle, Gaiman (2009) praises the device's ability to free him from a long drive to Florida with a trunkful of books, to make it possible for him to read during a flight from Beijing to Budapest, and to download last minute reading material for his daughter before a flight takes off. Gaiman's testimony very carefully elides the economic transaction that makes his Kindle so useful: he speaks of putting his reference material on the Kindle or having a genie stick books on the device. The necessary economic transaction is rendered invisible. Yoking the Kindle to long distance air travel becomes a way of articulating status issues once negotiated through the display of print books. ${ }^{9}$

The weight of the ebook device itself was originally a matter of concern for designers and users (Bryant, 1995; Looney \& Sheehan, 2001; Schilit, Price, Golovchinsky, Tanaka, \& Marshall, 1999; Waycott \& Kukulska-Hulme, 2003). This concern has been muted as the devices have become physically smaller and comments about weight have largely slipped out of the discourse about ebook devices. Similarly, concerns about screen glare and legibility have muted with advances in e-ink technologies and a shift away from backlighting. ${ }^{10}$ What persist are multiple concerns about the physical affordances that relate to how readers find

\footnotetext{
${ }^{9}$ For a review of the ways in which books and book culture have been used to negotiate and articulate status issues, see Manguel (1996) and Striphas (2009) .

${ }^{10}$ Renewed discussions of these factors is developing following the launch of the iPad given its weight, reflective screen, and use of backlighting.
} 
their way through a book. Early advocates of ebook devices acknowledged that the "fixed layout" of paper pages promoted "spatial memory," which increased the reader's ability to locate information (Schilit et al., 1999, p. 66). Studies of readers interacting with early ebook devices bore out this observation as readers of ebooks complained about the absence of key mnemonic elements. The layout of the pages of the paper book was, they reported, more effective for helping or allowing them to relocate information in the text: "I frequently know exactly where to find something l've read and want to return to, because I can picture in my head exactly where it is on the page" (Waycott \& Kukulska-Hulme, 2003, p. 35). Some ebook readers discovered that their reading experiences were hampered by not being able to quickly and physically judge where they were in the text: they missed the physicality that enabled "skipping ahead to sneak a peek at a page near the end of a book" (Fowler \& Baca, 2010). The frustration of long-established navigation habits makes the easily taken-for-granted affordances of paper pages and their page numbers visible. While the navigation advantages of the paper page cannot be easily addressed by designers, headway has been made by adding functionality that displays page numbers or a surrogate progress bar, hyperlinks chapter titles to tables of content, and allows the addition of electronic bookmarks. These changes in functionality have minimized but not entirely eliminated negative reading experiences (Pattuelli \& Rabina, 2010). In the end, these adjustments to ebook device affordances have not fully matched the affordances of print books, which offer readers a "serendipitous freedom as omnipotent navigators" who "dominate text, eagle-like in their overview, scanning at will any portion or section, leafing through pages, setting down to read at any point significant to mind and eye" (Brown, 2001, p. 393).

\section{Ebook Devices and Knowledge Workers}

As the functionality of devices has expanded over time, ebook advocates have become interested in the ways affordances unique to ebook devices might support the reading experiences of students and scholars. The ability to search across an entire book or to look up words in an integrated dictionary are commonly cited advantages. Preliminary studies of the way children use ebook devices have suggested that search and dictionary features are useful in establishing and developing literacy but that their utility varies somewhat in relation to the fluency of the reader (Larson, 2010): the more fluent the reader, the less need for the dictionary. Schools in England have begun to take advantage of the multimedia affordances of ebook devices to support students navigating schoolwork in a second language: English language written texts are supported by supplementary audio support in Polish (Morrison, 2009). Early assessments of child and adolescent users of ebook devices identify positive outcomes with an overall increase in the number of print and electronic books read (Harland, et al., 2010; Morrison, 2009). A similar pattern of increased book reading has been reported by adult users of ebook devices though it is not always clear that a distinction is being made between purchasing a book and reading a book (Fowler \& Baca, 2010; Harland, et al., 2010; Kelderman, 2010; Stross, 2010). 
While ebook devices can support the intellectual work of readers as they gain and create knowledge, digital reading also tends to encourage discontinuous reading experiences. Ebook devices privilege "quick reading, skimming, and scanning," which is well suited to "the needs of a highly time-constrained, highly-fragmented day" (Marshall \& Ruotolo, 2002, p. 63). Digital readers spend more time "browsing and scanning, keyword spotting," focusing on "one-time reading, non-linear reading," and selective reading than they spend deeply immersed in any single text (Liu, 2005, p. 705). Ultimately digital reading, whether on a personal computer or an ebook device, tends to encourage discontinuous reading experiences: ebook readers "skip around in the texts, focusing on some parts more closely than others", skimming, and "reading very quickly" to "locate and focus on short segments of a longer text" (Marshall \& Ruotolo, 2002, p. 58). As a result of this pattern of discontinuous reading, the majority of ebook readers spend less than one minute on an electronic page. For example, only $5.5 \%$ of students and $7.7 \%$ of professors read the ebooks they consult in their entirety (Baumann, 2010, p. 44). Given that "scholarly expert reading" is made up of the discontinuous tasks of reading, comparing, and analyzing multiple texts (Hillesund, 2010), this movement across multiple texts is not particularly surprising but it can be problematic.

The successful transition from reading to writing and the creation of new knowledge are dependent upon the kind of attention that is inherent in the note taking process. Creating annotations and notes improves retention and comprehension (Marshall \& Ruotolo, 2002; O'Hara \& Sellen, 1997) and, more importantly for knowledge workers, enables readers to make "relevant connections to their own writing" (Hillesund, 2010). While underlining, marginal marks, and brief notes do not have "explicit meaning to the computer, they have rich semantic meaning for people and enhance visual and episodic memory" and the "ability to make unstructured, free-form, idiosyncratic" marks on digital text is a fundamental affordance needed to support knowledge workers of all sorts (Schilit, et al. 1999, p. 67). Despite early hopes that ebook readers would create the digital equivalents of commonplace books to organize their reading experiences (Brown, 2001), later studies have indicated that the note taking capacities of ebook devices are inadequate to the task and thus under-utilized (Waycott \& KukulskaHulme, 2003). While devices have improved over time, note taking remains problematic. In a 2009 pilot study of Amazon's Kindle, more than half the university students who participated indicated that the device was not up to the task of organizing and managing their readings and notes (Damast, 2010). While ebook devices make it possible for readers to rapidly access multiple documents, adequate note taking and note management mechanisms remain key missing affordances.

\section{Conclusion}

Ebook devices do not yet provide effective methods for creating and recording interconnections among the discontinuity that characterizes digital reading practices. The memex, Vannevar Bush's imaginary device for finding, reading, sharing, and connecting 
loosely associated texts and ideas into more complex wholes, has not yet been realized. As an imaginary machine that allows readers to build trails of "interest through the maze of materials", Bush's memex will never have its affordances tested (Bush, 1945). With sufficient capital, an ebook device owner has easy and near instantaneous access to a startlingly wide range of content but further development is needed before ebook devices match the interconnecting ease of Bush's imagined machine. Ebook devices can support both the immersive reading of a single text and the expansive skimming of multiple texts, but have not yet crossed the critical hurdle of supporting the intertwined reading, note taking, and composition practices that are the foundation of creating new and meaningful texts. 


\section{References}

Armstrong, C. (2008). Books in a virtual world: The evolution of the e-book and its lexicon. Journal of Librarianship \& Information Science, 40(3), 193-206. doi:10.1177/0961000608092554

Baumann, M. (2010). Ebooks: A new school of thought. Information Today, 27(5), 1-48. Retrieved from http://www.infotoday.com/

Birkerts, S. (1994). The Gutenberg elegies: The fate of reading in an electronic age. Boston: Faber and Faber.

Borgman, C. (2007). Scholarship in the digital age: Information, infrastructure, and the Internet. Cambridge: MIT Press.

Bosman, J. (2010, December 8). Romance books are hot in the e-reading market. The New York Times. Retrieved from http://www.nytimes.com/2010/12/09/books/09romance.html

Brown, G. J. (2001). Beyond print: Reading digitally. Library Hi Tech, 19(4), 390-399. doi:10.1108/07378830110412456

Bryant, J. The paperless book. IEE Review, 41(6), 245-47. doi: 10.1049/ir:19950603

Burton, H. (1901-1914). Record 1825. [Excerpt]. Available from The Reading Experience Database: http://www.open.ac.uk/Arts/reading/recorddetails2.php?id=1825

Bush, V. (1945, July). As we may think. The Atlantic. Retrieved from http://www.theatlantic.com/magazine/archive/1969/12/as-we-may-think/3881/

Carr, N. (2010). The shallows: What the Internet is doing to our brains. New York: W.W. Norton.

Damast, A. (2010, June 11). E-Book readers bomb on college campuses. Business Week. Retrieved from http://www.businessweek.com/bschools/content/jun2010/bs20100610_200335.htm

Darnton, R. (2009). The case for books: Past, present, and future. New York: PublicAffairs. 
DuroSport Electronics. (2010). Smell of Books [Website]. Retrieved November 26, 2010 from http://smellofbooks.com/

Findlay, S. (2010, October 5). From e-books to no books. Maclean's. Retrieved from: http://oncampus.macleans.ca/education/2010/10/05/from-e-books-to-no-books/

Foderaro, L. W. (2010, October 19). In digital age, students still cling to paper textbooks. The New York Times. Retrieved from http://www.nytimes.com/2010/10/20/nyregion/20textbooks.html

Fowler, G. A., \& Baca, M. C. (2010, August 25). The ABCs of e-reading: New devices are changing habits; people are reading more, even while in a kayak. Wall Street Journal. Retrieved from http://online.wsj.com/article/SB10001424052748703846604575448093175758872.h tml

Gaiman, N. (2009). Neil Gaiman discusses Amazon Kindle. [Video] Retrieved from http://www.youtube.com/watch?v=80usYuj95Go

Gosse, E. (1859). Record 11243. [Excerpt]. Available from The Reading Experience Database: http://www.open.ac.uk/Arts/reading/recorddetails2.php?id=11243

Gregory, C. L. (2008). "But I want a real book": An investigation of undergraduates' usage and attitudes toward electronic books. Reference \& User Services Quarterly, 47(3), 266273. Retrieved from http://www.rusq.org/

Griffey, J. (2010). Ebook sanity. Library Journal, 135(13), 25-26. Retrieved from http://www.libraryjournal.com/lj/communityopinion/885940274/ebook_sanity.html.csp

Griswold, W., McDonnell, T., \& Wright, N. (2005). Reading and the reading class in the twentyfirst century. Annual Review of Sociology, 31, 127-141. doi:10.1146/annurev.soc.31.041304.122312

Harland, P., Plante, A., Marker, J., Falter, C., Thompson, K., Guilmett, K., \& Hogan, M. (2010). The high school book club--Now with Kindles! Teacher Librarian, 37(5), 57-59. 
Heffernan, V. (2010a, March 4). Shelf life. The New York Times Magazine. Retrieved November 26, 2010 from http://www.nytimes.com/2010/03/07/magazine/07FOBmedium-t.html?ref=virginia_heffernan

Heffernan, V. (2010b, October 15). E-readers collective. The New York Times Magazine. Retrieved from http://www.nytimes.com/2010/10/17/magazine/17FOB-medium-t.html

Herther, N. K. (2008). The ebook reader is not the future of ebooks. Searcher, 16(8), 26-40. Retrieved from http://www.infotoday.com/searcher/sep08/index.shtml

Hillesund, T. (2010). Digital reading spaces: How expert readers handle books, the Web and electronic paper. First Monday (Online). Retrieved from http://firstmonday.org/htbin/cgiwrap/bin/ojs/index.php/fm/article/view/2762/2504

Jackson, H. (2001). Marginalia: readers writing in books. New Haven: Yale University Press.

Johnson, S. (2010, June 19). Yes, people still read, but now it's social. The New York Times. Retrieved from http://www.nytimes.com/2010/06/20/business/20unbox.html

Kelderman, E. (2010, June 13). E-readers advance in academe: A "Chronicle" survey. The Chronicle of Higher Education. Retrieved from http://chronicle.com/article/EReaders-Advance-in-Academe-/65885/

Larson, L. C. (2010). Digital readers: The next chapter in e-book reading and response. Reading Teacher, 64(1), 15-22. doi:10.1598/RT.64.1.2

Levy, S. (2007). The future of reading. Newsweek, 150(22), 56-64. Retrieved from http://www.newsweek.com/2007/11/17/the-future-of-reading.html

Li, C., \& Bernoff, J. (2008). Groundswell: Winning in a world transformed by social technologies. Boston: Harvard Business Press.

Liu, Z. (2005). Reading behavior in the digital environment: Changes in reading behavior over the past ten years. Journal of Documentation, 61(6), 700-712. doi:10.1108/00220410510632040

Looney, M. A., \& Sheehan, M. (2001). Digitizing education: A primer on ebooks. Educause Review, 36(4), 38-46. Retrieved from http://www.educause.edu/EDUCAUSE+Review/EDUCAUSEReviewMagazineVolum e36/DigitizingEducationAPrimeroneB/157702 
Lynch, C. (1999). Electrifying the book. Library Journal, 124(17), 3-6. Retrieved from http://www.libraryjournal.com

Lynch, C. (2000). Electrifying the book, Part 2. Library Journal, 125(1), 24-27. Retrieved from http://www.libraryjournal.com

Machrone, B. (1998). Electronic books a horror story? Readers think so. PC Week, 15(42), 81. Retrieved from Academic Search Premier.

Manguel, A. (1996). A history of reading. Toronto: A.A. Knopf Canada.

Marshall, C. C., \& Ruotolo, C. (2002). Reading-in-the-small: A study of reading on small form factor devices. Proceedings of the second ACM/IEEE-CS joint conference on digital libraries - JCDL '02. 56-64. doi:10.1145/544220.544230

Morrison, N. (2009, February 20). Broken spines. Times Educational Supplement. Retrieved from http://www.tes.co.uk/article.aspx?storycode $=6009036$

Norman, D. (2002). The design of everyday things. New York: Basic Books.

O'Hara, K., \& Sellen, A. (1997). A comparison of reading paper and on-line documents. Presented at the SIGCHI conference, Atlanta, Georgia, United States. Retrieved from http://www.sigchi.org/chi97/proceedings/paper/koh.htm

O'Reilly, T. (2005, September 30). What is Web 2.0: Design patterns and business models for the next generation of software. O'Reilly Media. Retrieved from http://oreilly.com/

Oder, N., Albanese, A., \& Kuzyk, R. (2009, March 15). The social downside to ebook readers. Library Journal, 134(9), 16. Retrieved from http://www.libraryjournal.com/lj/linprintcurrentissue/854331-403/newsdesk.html.csp

Pattuelli, M. C., \& Rabina, D. (2010). Forms, effects, function: LIS students' attitudes towards portable e-book readers. Aslib Proceedings, 62(3), 228-244. doi:10.1108/00012531011046880

Pogue, D. (2009, July 17). Some E-books are more equal than others. The New York Times. Retrieved from http://pogue.blogs.nytimes.com/2009/07/17/some-e-books-are-moreequal-than-others/ 
Raab, R. (2010). Books and literacy in the digital age. American Libraries, 41(8), 34-37. Retrieved from http://americanlibrariesmagazine.org/features/07132010/books-andliteracy-digital-age

Schilit, B. N., Price, M. N., Golovchinsky, G., Tanaka, K., \& Marshall, C. (1999). The reading appliance revolution. Computer, 32(1), 65-73. doi:10.1109/2.738306

Shelburne, W. A. (2009). E-book usage in an academic library: User attitudes and behaviors. Library Collections, Acquisitions, and Technical Services, 33(2-3), 59-72. doi:10.1016/j.lcats.2009.04.002

Shirky, C. (2008). Here comes everybody: The power of organizing without organizations. New York: Penguin Press.

Striphas, T. (2009). The late age of print: Everyday book culture from consumerism to control. New York: Columbia University Press.

Striphas, T. (2010). The abuses of literacy: Amazon Kindle and the right to read. Communication and Critical/Cultural Studies, 7(3), 297. doi:10.1080/14791420.2010.504597

Stross, R. (2010, August 7). E-Book wars: The specialist vs. the multitasker. The New York Times. Retrieved from http://www.nytimes.com/2010/08/08/business/08digi.html

Tennant, R. (2000). The emerging role of e-books. Library Journal, 125(13), 38. Retrieved from http://www.libraryjournal.com

Waycott, J. (2002). Reading with new tools: An evaluation of personal digital assistants as tools for reading course materials. Association for Learning Technology Journal, 10(2), 38-50. doi:10.1080/0968776020100205

Waycott, J., \& Kukulska-Hulme, A. (2003). Students' experiences with PDAs for reading course materials. Personal and Ubiquitous Computing, 7(1), 30-43. doi:10.1007/s00779002-0211-xReference follows APA $6^{\text {th }}$ edition with a hanging indentation of 0.75 ". The spacing is still 1.15. text is 12 pt Arial, black, and 1.15 spacing. Reference follows APA $6^{\text {th }}$ edition with a hanging indentation of 0.75 ". The spacing is still 1.15 . text is 12 pt Arial, black, and 1.15 spacing. 